\title{
Media Pop Up Book Sebagai Alat Peningkatan Keterampilan Berbicara Siswa
}

\author{
Murniati $^{1}$, Rien Anitra ${ }^{2}$ \\ Pendidikan Guru Sekolah Dasar STKIP Singkawang, Singkawang, Indonesia ${ }^{1}$ \\ Pendidikan Guru Sekolah Dasar STKIP Singkawang, Singkawang, Indonesia ${ }^{2}$ \\ uni.murniati18@gmail.com ${ }^{1}$, anitrarien@gmail.com ${ }^{2}$
}

\section{Keywords : \\ Media Pop Up Book, \\ Keterampilan Berbicara}

\begin{abstract}
Peningkatan keterampilan berbicara merupakan suatu aspek penting yang dapat menunjang untuk mahir dalam berkomunikasi. Penulisan artikel ini bertujuan untuk mengkaji dan menganalisis media Pop-Up Book dalam meningkatkan keterampilan berbicara siswa. Artikel ini merupakan hasil analisis dengan mengkaji literatur yang memiliki keterkaitan dengan topik pembahasan. Model yang digunakan adalah studi literatur atau lirature riview. Dari hasil penelaahan, hasil yang didapat menunjukkah bahwa peningkatan keterampilan berbicara siswa dapat ditingkatkan dengan menggunakan media pembelajaran. Satu diantaranya yaitu media dengan desain tiga dimensi yang menarik dan dapat merangsang pemikiran siswa, dan media pembelajaran yang dapat digunakan adalah media Pop-Up Book. sehingga dapat ditarik kesimpulan bahwa media Pop-Up Book dapat meningkatkan keterampilan berbicara siswa dikarenakan desain tiga dimensi yang dapat membantu siswa menemukan ide-ide serta dapat mengungkapkan ide tersebut dengan jelas.
\end{abstract}




\section{INTRODUCTION}

Media pembelajaran merupakan suatu alat atau sarana untuk menyampaikan materi pelajaran kepada siswa. Penggunaan media dalam proses pembelajaran mampu mengubah suatu konsep yang abstrak menjadi konkret. Sehingga memudahkan siswa untuk memahami materi dan guru terbantu karena tidak perlu banyak biacara untuk menjelaskan materi pelajaran kepada siswa. Sementara itu menurut Peraturan Menteri Pendidikan Dan Kebudayaan Nomor 22 Tahun 2016 Tentang Standar Proses Pendidikan Dasar Dan Menengah bahwa proses pembelajaran pada satuan pendidikan diselenggarakan secara interaktif, inspiratif, menyenangkan, menantang, memotivasi pesertadidik untuk berpartisipasi aktif, serta memberikan ruang yang cukup bagi prakarsa, kreativitas, dan kemandirian sesuai dengan bakat, minat, dan perkembangan fisik serta psikologis peserta didik. Oleh karena itu, dalam kegiatan proses pembelajaran guru harus mampu menciptakan suasana belajar yang kondusif, menarik dan interaktif antar guru dan siswa, dengan suasana kelas yang interaktif siswa menjadi tidak bosan dan lebih bersemangat dalam mengikuti pembelajaran. Menurut referensi Pramesti, J.(2015) media Pop-Up Book adalah media berbentuk buku yang mempunyai unsur tiga dimensi dan gerak. Pada Pop-Up Book, materi disampaikan dalam bentuk gambar yang menarik karena terdapat bagian yang jika dibuka dapat bergerak, berubah atau memberi kesan timbul. Menurut referensi Fauzi. R.F. (2018) menyatakan bahwa media buku Pop-Up Book merupakan buku yang menampilkan halaman-halaman buku yang di dalamnya lipatan gambar yang dipotong yang membentuk lapisan tiga dimensi yang dapat pula digerakan sehingga membuat pengguna buku tidak mudah bosan.

Seiring dengan perkembangan teknologi yang pesat saat ini memberikan dampak yang signifikan pada aspek kehidupan manusia. Satu diantaranya adalah aspek komunikasi. Menurut referensi (Nawawi, dkk. 2017) komunikasi adalah sebuah proses interaksi yang saling berhubungan dari satu pihak ke pihak lainnya. Oleh karena itu dalam berinteraksi dengan orang lain kita memerlukan penguasaan keterampilan berbahasa, terutama keterampilan menyimak dan berbicara yang dapat menunjang kelancaran kita saat berkomunikasi. Menurut referensi (Saifuddin. 2015) menyatakan bahwa keterampilan berbahasa terdiri dari empat aspek, yaitu menyimak atau mendengarkan, berbicara, membaca, dan menulis. Oleh sebab itu, keterampilan berbahasa siswa penting untuk ditingkatkan, agar siswa mampu menggunakan bahasa sebagaimana fungsinya, yaitu sebagai alat komunikasi. Dengan demikian, aspek yang menjadi fokus utama masalah penelitian ini adalah tentang keterampilan berbicara.

Keterampilan berbicara tidaklah dimiliki oleh semua orang, tetapi dapat dimiliki oleh sebagian orang yang mau berlatih bersungguh-sungguh untuk terampil berbicara. Terampil dalam berbicara juga bukan bakat dari lahir, karena keterampilan dalam berbicara merupakan hasil dari pengaruh lingkungan yang melatih diri untuk belajar mengucapkan kata demi kata, kalimat demi kalimat, hingga menjadi suatu ungkapan yang bermakna dan dapat dipahami oleh orang lain. Oleh sebab itu, keterampilan berbicara siswa di sekolah perlu untuk ditingkatkan sebagai bekal keterampilan siswa nantinya untuk berkomunikasi dengan orang lain saat akan melanjutkan ke jenjang pendidikan yang lebih tinggi lagi.

Keterampilan berbicara siswa dapat ditingkatkan dengan melibatkan media dalam kegiatan pembelajaran. Media yang dapat mengembangkan keterampilan berbicara siswa adalah media Pop-Up Book. Menurut referensi (Astuti. R. 2015) menyatakan bahwa media Pop-Up Book melibatkan siswa untuk berpikir mengembangkan cerita secara lisan dari pengetahuan yang telah dimiliki. Sehingga siswa akan lebih mudah menceritakan suatu peristiwa yang pernah dialami, dilihat, atau didengar menggunakan media pembelajaran berupa Pop-Up Book. Guru berperan menggali pengetahuan yang dimiliki siswa dengan pertanyaan-pertanyaan eksplorasi (menggali) yang berkaitan dengan objek pada media Pop-Up Book. Menurut referensi (Santoso. B. A. 2015) menyatakan bahwa Pop-Up Book ini berisi gambar-gambar yang dibentuk sehingga menyerupai tiga dimensi. Media ini dapat digunakan dalam pembelajaran bahasa untuk meningkatkan keterampilan dasar berbahasa, yang salah satunya yaitu keterampilan berbicara. 
Terampil berbicara merupakan keterampilan yang harus dimiliki oleh setiap individu, karena berbicara sebagai perantara seseorang untuk menyampaikan ide, pikiran, perasaan, dan sebagainya yang ingin ia sampaikan kepada pendengar. Oleh sebab itu apabila ia tidak terampil dalam menyampaikan isi hati dan pikiran tersebut, maka akan sulit dalam menyampaikan pesan tersebut dan menjadi salah makna karena Antara pikiran dan ucapannya tidak selaras. Dalam hal ini, keterampilan berbicara siswa harus ditingkatkan untuk bekal mereka dalam kehidupan sosial di sekolah, di rumah, maupun di masyarakat, agar mereka terampil dalam berkomunikasi dengan orang lain. Karena bahasa atau segala yang diucapkan seseorang dapat mencerminkan pikirannya. semakin mahir seseorang dalam berbahasa maka semakin cerah dan jelas pula jalan pikirannya.

Paparan di atas menunjukkan bahwa media Pop-Up Book dapat menjadi alat untuk meningkatkan keterampilan berbicara peserta didik di sekolah. Tidak cukup jika guru hanya menerapkan metode, model, strategi dan sebagainya ketika mengajar. Peranan media pembelajaran sangatlah penting untuk membantu guru saat mengajar. Analisis ini mencoba mengkaji media Pop-Up Book sebagai alat untuk meningkatkan keterampilan berbicara siswa SD di sekolah.

\section{METHOD}

Artikel ini menggunakan studi literatur atau literature riview dengan menganalisis beberapa kajian yang berkaitan dengan topik pembahasan yaitu pendidikan, media Pop-Up Book, dan keterampilan berbicara. Sumber-sumber rujukan yang menjadi pokok bahasan bersumber dari buku, jurnal artikel, prosiding dan yang lainnya. hal tersebut dimaksudkan untuk meninjau media Pop-Up Book sebagai alat peningkatan keterampilan berbicara siswa di sekolah.

\section{RESULTS AND DISCUSSIONS}

\section{Keterampilan Berbicara}

Keterampilan berbicara merupakan kemampuan seseorang untuk memenuhi kebutuhan berkomunikasinya. Keterampilan berbicara sangatlah penting bagi manusia utamanya siswa SD karena keterampilan berbicara ini tidak lepas hubungannya dengan kehidupan sehari-hari. Pada siswa SD kelas rendah keterampilan berbicara ini harus terus dilatih agar lebih terampil berkomunikasi dengan orang tua, guru, dan teman sejawatnya karena tujuan utama dari berbicara adalah sebagai alat komunikasi (Santoso. B. A. 2015). Berbicara adalah suatu bentuk kegiatan penyampaian pesan yang berisi ide, gagasan maupun perasaan yang dimiliki seseorang kepada orang lain secara lisan dengan tujuan agar penerima pesan dapat memahami isi pesan yang disampaikan. Berbicara menjadi keterampilan berbahasa yang penting untuk dipelajari sebaik mungkin karena dapat memberikan kelancaran dan kemudahan bagi segala urusan yang kita lakukan dalam kehidupan. Dalam kehidupan sehari-hari tentu kita setiap waktu pasti akan berbicara tentang sesuatu apapun itu. Berinteraksi, mengobrol dan berkomunikasi tentulah melibatkan keterampilan berbicara yang kita miliki. Apabila kamu terlihat tidak pandai berbicara dan banyak diamnya maka kamu akan dianggap tidak pandai dalam berkomunikasi dengan orang lain dan kamu akan sulit untuk berinteraksi dengan lingkungan social di sekitarmu.

Kemampuan berbicara yang diharapkan dari pembelajaran di sekolah adalah agar siswa terampil berbicara. Keterampilan berbicara yang diharapkan adalah kemampuan mengungkapkan pendapat, ide, gagasan, pemikiran, atau perasaannya di muka umum dalam bahasa Indonesia yang baik dan benar. Kemampuan berbicara dalam segala situasi inilah yang belum dimiliki oleh sebagian besar masyarakat Indonesia. Persoalan paling serius pada siswa kita dalam bidang berbicara saat ini adalah jika mereka diminta berbicara di depan umum, mereka akan diam dan garuk-garuk kepala. Akan tetapi, jika diminta diam mereka malahan akan berbicara (berbisik-bisik) dengan temannya. Mereka akan berbicara dengan teman atau orang-orang di sekelilingnya. Kondisi yang demikian dijumpai tidak hanya pada siswa-siswi saja, Kondisi seperti itu juga kerap ditemukan di kalangan orang dewasa. Bangsa kita tidak mampu berbicara di depan umum dengan baik (Tambunan. P. 2016). 
Seperti yang telah dibahas di atas bahwa setiap hari kita pasti melakukan komunikasi dengan orang lain, baik secara langsung maupun tidak langsung. Berbicara merupakan suatu kegiatan yang dilakukan untuk menyampaikan ide, pesan, gagasan, serta perasaan dari pembicara tersebut, sehingga orang lain dapat memahami apa yang pembicara ucapkan.

\section{Tujuan Berbicara}

Tujuan utama dari berbicara adalah untuk berkomunikasi. Agar dapat meyampaikan pikiran secara efektif, maka pembicara harus memahmami segala seseuatu yang ingin dikomunikasikan. Adapaun secara umum, berbicara mempunyai tiga maksud yaitu: a.Memberitahukan dan melaporkan (to inform)Berbicara untuk memberitahukan dan melaporkan maksudnya berbicara untuk memberikan informasi, membeerikan atau menanamkan pengetahuan, menerangkan atau menjelaskan sesuatu proses dan menginterprestasikan atau menafsirkan sesuatu persetujuan ataupun menguraikan sesuatu tulisan. b. Menjamu dan menghibur (to entertain) berbicara untuk menjamu dan menghibur maksudnya berbicara untuk menghibur orang lain. c. Membujuk, mengajak, mendesak dan meyakinkan (to persuade) Berbicara untuk membujuk, mengajak, mendesak dan meyakinkan maksudnya berbicara bertujuan untuk kalau kita menginkan tindakan atau aksi. Pembicaraan yang bersifat persuasif disampaikan kepada pendengar apabila kita menginginkan penampilan suatu tindakan.Pembelajaran berbicara dilakukan dengan tujuan agar peserta didik dapat mengekspresikan gagasannya sedemikian rupa, sehingga orang lain mau dan tertarik untuk mendengarkan apa yang dibicarakan tersebut. Program pembelajaran berbicara harus mampu memberikan kesempatan kepada peserta didik untuk mencapai tujuan yang dicita-citakan. Sehubungan dengan hal tersebut, Fowler berpendapat bahwa tujuan ketrampilan berbicara mencakup hal-hal berikut: 1)Mudah dan lancar atau fasih. Agar tujuan tersebut dapat tercapai, maka anak didik harus mendapat kesempatan untuk berlatih berbicara sampai mereka mengembangkan ketrampilan berbicara secara wajar,lancar, danmenyenangkan melalui pembentukan kelompok diskusi kecil maupun di hadapan teman-temannya. 2) Kejelasan, Hal ini dimaksudkan agar peserta didik dapat berbicara dengan tepat dan jelas baik artikulasi, diksi, maupun kalimat-kalimatnya. Hal tersebut dapat terwujud apabila peserta didik sering melakukan latihan diskusi. 3)Bertanggung JawabMaksud dari tanggung jawab disini adalah peserta didik mampu berbicara secara tepat, menyadari dengan sungguh-sungguh mengenai topik yang dibicarakan, mengenai tujuan pembicaraan, menyadari siapa yang diajak berbicara, bagaimana situasinya, dsb.4)Membentuk pendengaran yang kritisLatihan berbicara yang baik adalah latihan yang di dalamnya mengembangkan ketrampilan menyimak mendengarkan secara tepat dan kritis sekaligus. Disini peserta didik perlu dilatih mengevaluasi kata-kata, niat, dan tujuan pembicara yang dapat dilakukan dengan mengajukan pertanyaan : siapakah yang berkata? mengapa berkata demikian?, benarkah yang diucapkannya itu?apa tujuannya?, dsb. Secara umum, tujuan berbicara ialah agar peserta didik mampu berkomunikasi lisan secara sederhana, seperti bercerita, berdiskusi, menyampaikan pendapat/ide. Oleh karena itu, dalam pembelajarannya guru harus mampu menggugah dan memotivasi siswa untuk berbicara dan mempunyai keberanian untuk mempraktikannya di depan kelas (Faujiyah. A . 2018).

Tujuan utama berbicara adalah untuk berkomunikasi. Menurut referensi (Maryana, D. 2018) menyatakan bahwa tujuan berbicara sebagai berikut; (1) Mendorong pembicara untuk memberi semangat, membangkitkan kegairahan, serta menunjukan rasa hormat dan pengabdian. (2) Meyakinkan (3) Berbuat atau bertindak (4) Memberitahukan. (5) Menyenangkan.

\section{Jenis-jenis Keterampilan Berbicara Dalam Proses Pembelajaran}

Astuti (2015) menyatakan bahwa bentuk atau jenis keterampilan berbicara dalam pembelajaran antara lain: (1) percakapan atau berdialog; (2) mendongeng atau bercerita; 
Sejalan dengan referensi (Nawawi, dkk. 2017) yang menyatakan jenis - jenis berbicara ditinjau dari berbagai aspek : pertama, berdasarkan situasi, berbicara ada dalam dua lingkup jika dilihat dari situasinya, yaitu lingkup resmi dan lingkup tidak resmi. Situasi - situasi resmi dapat dikelompokkan kedalam klasifikasi informatif seperti :Kuliah, ceramah tentang perjalanan, laporan, instruksi, pemberian suatu pandangan, pengangkatan atau penunjukkan, pidato. Sedangkan situasi tidak resmi berupa situasi yang mengandung unsur hiburan seperti : anekdot, lelucon atau lawakan, arisan, perkumpulan keluarga, pesta ulang tahun. Kedua Berdasarkan tujuan, berbicara dilihat dari tujuan yang ingin dicapai dapat dibagi menjadi lima jenis, yaitu ; berbicara menghibur, berbicara menginformasikan, berbicara menstimulasi, berbicara meyakinkan, berbicara menggerakkan. Ketiga berdasarkan metode dan teknik penyampaian berbicara Banyak macam metode dalam penyampaian berbicara yang digunakan seseorang dalam menyampaikan pembicaraannya, diantaranya adalah metode penyampaian mendadak, metode penyampaian naskah, metode penyampaian catatan kecil, metode penyampaian hafalan. Teknik berbicara dilaksanakan agar pembicaraan lebih mudah dimengerti dan mencapai tujuan yang diharapkan. Penyesuaian diri antara komunikator dan komunikan sangat dibutuhkan. Keempat berdasarkan jumlah penyimak, berdasarkan jumlah penyimaknya, berbicara dapat dibagi atas tiga jenis ; berbicara antarpribadi, berbicara dalam kelompok kecil, dan berbicara dalam kelompok besar.

\section{Pembelajaran Keterampilan Berbicara Menggunakan Media Pop-Up Book}

Keterampilan berbicara merupakan keterampilan untuk melisankan bunyi-bunyi artikulasi atau bunyi bahasa untuk mengekspresikan, menyatakan, atau menyampaikan gagasan, pikiran, dan perasaan seseorang agar dapat dipahami oleh orang lain. Salah satu bentuk kegiatan berbicara adalah bercerita. Siswa sering kali merasa kesulitan untuk bercerita karena tidak memiliki bahan. Oleh sebab itu perlu adanya media sebagai sumber bahan cerita. Salah satu media yang dapat digunakan dalam kegiatan bercerita adalah media pop up book. Media pop up book sebagai rangsang visual yang menjadi sumber bahan cerita bagi siswa.

Langkah pembelajaran menggunakan media pop up book juga dibantu dengan peta konsep agar siswa mampu bercerita secara runtut. Adapun langkah-langkah pembelajaran bercerita menggunakan media pop up book yaitu sebagai berikut:1. Siswa mendengarkan penjelasan dari guru tentang langkah-langkah kegiatan pembelajaran yang akan dilakukan. 2. Siswa mendengarkan penjelasan dari guru tentang unsur-unsur intrinsik cerita dan tata cara bercerita yang baik sesuai dengan aspek kebahasaan dan nonkebahasaan. 3. Guru menentukan tema cerita sesuai dengan objek pada media pop up book. 4. Siswa mengamati sebuah pop up book yang dibawa guru ke dalam kelas. 5. Siswa dan guru melakukan tanya jawab untuk menggali pengetahuan yang dimiliki siswa serta dihubungkan dengan jenis pekerjaan dan manfaat uang berdasarkan objek pada pop up book 6. Jawaban-jawaban siswa ditulis di papan tulis dalam bentuk peta konsep sesuai dengan unsur-unsur intrinsik cerita. 7. Siswa diberi contoh menceritakan sebuah cerita dari peta konsep yang telah ditulis di papan tulis. 8. Siswa menyimak atau mendengarkan cerita yang disajikan oleh guru. 9. Siswa diberi tugas untuk bercerita di depan kelas tentang peristiwa yang pernah dialami, dilihat, atau didengar berdasarkan media rangsang visual berupa pop up book. Namun terlebih dahulu siswa diminta untuk membuat peta konsep seperti yang telah dicontohkan oleh guru. 10. Siswa mengembangkan peta konsep yang telah dibuat ke dalam draft cerita atau dalam bentuk kalimat-kalimat. 11. Siswa secara individu latihan bercerita di tempat duduk masingmasing dengan mengembangkan draft cerita yang telah dibuat. 12. Masing-masing siswa diberi kesempatan untuk bercerita di depan kelas dengan cara pengembangan dari peta konsep dan draft cerita peristiwa yang telah dibuat. 13. Siswa diberi kesempatan untuk bertanya atau menanggapi cerita pengalaman yang diceritakan oleh temannya. 14. Siswa memperoleh perbaikan dari kegiatan bercerita yang tidak sesuai dengan aspek kebahasaan dan nonkebahasaan. 15. Guru mengadakan evaluasi berupa tes bercerita untuk mengukur keterampilan berbicara siswa. 16. Guru bersama siswa menyimpulkan hasil pembelajaran. 


\section{CONCLUSION AND SUGGESTION}

Berbicara adalah suatu bentuk kegiatan penyampaian pesan yang berisi ide, gagasan maupun perasaan yang dimiliki seseorang kepada orang lain secara lisan dengan tujuan agar penerima pesan dapat memahami isi pesan yang disampaikan. Berbicara menjadi keterampilan berbahasa yang penting untuk dipelajari sebaik mungkin karena dapat memberikan kelancaran dan kemudahan bagi segala urusan yang kita lakukan dalam kehidupan. Untuk meningkatkan keterampilan berbicara diperlukan suatu media yang mampu untuk merangsang siswa dalam mengembangkan ide, gagasan serta perasaan sehingga siswa mampu menyampaikan ide tersebut dengan baik, dan dapat dipahami oleh orang lain. Media yang paling efektif untuk digunakan adalah media Pop-Up Book. Dengan desain tiga dimensi menjadi kan siswa tertarik, dan dapat merangsang pemikiran siswa dalam mengembangkan ide dan perasaan siswa. Sehingga media ini dipercayai efektif untuk meningkatkan keterampilan berbicara.

Saran saya, untuk para pendidik hendak memperhatikan akan kebutuhan, minat, serta karakteristik siswa. Sehingga dapat menentukan apa saja yang harus dilakukan terutama dalam memilih media yang cocok. Agar tujuan pembelajaran dapat dicapai dengan optimal.

\section{REFERENCES}

Astuti. R. (2015). Peningkatan Keterampilan Berbicara Menggunakan Media Pop Up Book Siswa Kelas III SD Negeri Gembongan Kecamatan Sentolo Kabupaten Kulon Progo Tahun Ajaran 2014/2015. Yogyakarta : Universitas Negeri Yogyakarta.

Faujiyah. A . (2018). Kemampuan Berbicara Siswa Kelas V (Umar Bin Khatab)Pada PembelajaranTematik Di Min 1 Banyumas. Institut Agama Islam Negeri Purwokerto : Purwokerto.

Fauzi. R.F. (2018). Peningkatan Motivasi Belajar IPS Melalui Media Pop Up Book Pada Siswa Kelas IV SDN Gamping Sleman Yogyakarta. Universitas Negeri Yogyakarta : Yogyakarta.

Maryana, D. (2018). Kemampuan Berbahasa Indonesia Siswa Kelas VSD Negeri 4 Metro Timur Tahun Pelajaran 2017/2018. Universitas Lampung : Bandar Lampung.

Nawawi, dkk. (2017). Keterampilan Berbicara Sebagai Suatu Keterampilan Berbahasa. Jakarta : Uhamka Press.

Nawawi, dkk. (2017). Keterampilan Berbicara Sebagai Suatu Keterampilan Berbahasa. Jakarta : Uhamka Press. Hal. 24-25.

Pramesti, J.(2015). Perkembangan Media Pop Up Book Tema Peristiwa Untuk Kelas III SD. Universitas Negeri Yogyakarta : Yogyakarta.

Saifuddin. (2015). Peningkatan Keterampilan Berbicara Dengan Menggunakan Media Gambar Dalam Pembelajaran Bahasa Indonesia Kelas V MI AL-Husna Jurang Mangu Tangerang Selatan. Jakarta: UIN Syarif Hidayatullah.

Santoso. B. A. (2015). Peningkatan Keterampilan Berbicara Menyampaikan Tanggapan Melalui Model Talking Stick Berbantuan Media Gambar Pada Siswa Kelas III SDN Tugurejo 03 Semarang. Semarang : Universitas Negeri Semarang.

Tambunan. P. (2016). Pembelajaran Keterampilan Berbicara di Sekolah Dasar. - : Universitas Quality. 